DOI https://doi.org/10.32782/2305-9389/2020.23.17

УДК 32.019.52

Заславська Ольга,

кандидат політичних наук,

доцент кафедри філософії і політології

Хмельницького національного університету

Налімова Вікторія, студентка факультету міжнародних відносин Хмельнищького національного університету

Посвістак Олеся, доктор психологічних наук, професор кафедри філософії $і$ політології Хмельницького національного університету

\title{
ЕМАНСИПАЦЙНІ ЦІННОСТІ СУЧАСНОГО УКРАЇНСЬКОГО СУСПІЛЬСТВА В УМОВАХ ДЕМОКРАТИЗАЦІЇ ПОЛІТИЧНОЇ КУЛЬТУРИ
}

У статті проведено порівняльний аналіз емансипаційних иінностей украӥниів із ціннісними орієнтаціями європейців у 2020 рочі. Критерієм порівняння вибрано бачення громадянами важливості окремих характеристик демократії. Встановлено, щзо оиінка україниями демократичної політичної системи, позитивне ставлення до рівності прав жінок і чоловіків та вибору політичних лідерів на вільних виборах є досить високими в Україні, проте все щее залишаються одними з найнижчих серед всіх крайн $С С$, вибраних для порівняння. Визначено, щчо за рівнем усвідомлення важливості захисту громадянських прав Україна знаходиться в середині списку з країн ЄC, включених до порівняння. 3'ясовано, щзо частка україниів, переконаних у необхідності державної допомоги безробітним, стягування податків із багатих для підтримки бідних, забезпечення рівності доходів із боку держави, важливості підкорення людей своїм правителям, керівникам, можливості переходу влади до рук армії за умов недієздатності уряду, одноосібного тлумачення законів релігійними авторитетами, є вищою в Україні, ніж у більшості краӥн Свропейського Союзу, однак частка українців, впевнених у тому, що повага до прав людини є важливою складовою частиною демократії, суттєво нижча. Встановлено, щзо сегментматеріалістів в Україні є одним із найбільших, а постматеріалистів, відповідно, - одним із найменших серед країн Свропейського Союзу.

Прослідковано зміну ціннісних орієнтацій украйнців з 2011 року та встановлено, щуо значно популярнішими стали думки про необхідність підкорення правителям, взяття влади до рук армії, якщо уряд некомпетентний, одноосібного тлумачення законів релігійними авторитетами та водночас необхідності поважати права людини при демократії.

Визначено, щзо збереження та зміцнення демократії безпосередньо пов'язане зі зміною типу політичної культури.

Ключові слова: емансипаційні иінності, демократія, громадянські права, політична система, політична культура.

Zaslavska Olha, Nalimova Viktoriia, Posvistak Olesia. Emancipation values of modern Ukrainian society in the conditions of democratization of political culture

The article is a comparative analysis of the emancipatory values of Ukrainians with the value orientations of Europeans in 2020. The criterion for comparison is the idea of the importance of certain characteristics of democracy. It is established that Ukrainians' assessment of the democratic political system, positive attitude towards equality of women's and men's rights and election of political leaders in free elections in Ukraine are quite high, but still remain among the lowest among all European Union countries selected for comparison. It is determined that the level of awareness of the importance of protection of civil rights in Ukraine is in the middle of the list of EU countries included in the comparison. It was found that the share of Ukrainians who believe that respect for human rights is an important component of democracy is much lower than in most European Union countries. It is established that the segment of materialists in Ukraine is one of the largest among the European Union countries. It is determined that the segment of postmaterialists in our country is one of the smallest among the countries of the European Union.

The values of our compatriots have changed since 2011. It has been found that the need to obey rulers, transfer power to the army, interpret the laws of religious leaders, and respect human rights in a democracy has become much more popular. At the same time, there is a significant increase in understanding of the need to respect human rights in a democracy.

It is determined that the preservation and strengthening of democracy are directly related to the change in the type of political culture. The formation of democracy is associated with constant work with the value orientations of the people, which are deeply rooted in his subconscious.

Key words: emancipatory values, democracy, civil rights, political system, political culture. 
Нині в Україні відбуваються зміни, пов'язані з курсом суспільства і держави на демократизацію політичної системи. А рух до демократії не можливий без політичної освіти громадян та розвитку політичної культури. Окремі проблеми політичної культури часто стають предметом наукових досліджень, однак досі залишаються поширеними спрощені уявлення про цей феномен. Так, оцінка стану політичної культури часто обмежується аналізом рейтингів довіри населення до органів влади чи окремих політиків, з'ясуванням електоральних уподобань тощо. Більшість дослідників стану політичної культури в Україні будують свою роботу саме на розумінні політичної культури як ставлення 3 повагою усіх членів спільноти до цінностей «соціального капіталу», встановлення й дотримання певного порядку, що зумовлений не усталеними традиціями чи санкціями, а вмінням і прагненням індивідів домовлятися.

Зміна цінностей у сучасний період $є$ предметом багаторічних досліджень у рамках світового проєкту WVS (World Values Survey) [11]. Окремі проблеми емансипаційних цінностей перебувають у полі зору Р. Інглхарта, К. Вельцеля, С. Харрісона, Дж. Александера та ін. [1; 2; 3], які розглядають їх крізь призму глобалізаційних змін, соціально-економічного росту та демократизації суспільств. Доречно згадати роботи 3. Баумана, Н. Лумана, У. Бека, Е. Гідденса та ін. [4], які вписують глобалізаційні аспекти модернізації в контекст становлення індивідуалізму. Аналіз особливостей ціннісних змін у сучасній Україні у взаємозв'язку з чинниками національної ідентичності маємо у працях Н. Паніної, С. Рябова, Ю. Савельєва, В. Місютіної, А. Ручки, О. Кожемякіної та ін. Так, О. Кожемякіна з позицій архетипового підходу розкриває соціокультурну сутність емансипаційної динаміки ціннісних перетворень глобалізованої сучасності та розглядає взаємозв'язок емансипаційних цінностей зі становленням культури довіри та формуванням структур громадянського суспільства в контексті особливостей української ментальності та у співвідношенні індивідуальних та колективних цілей [6]. Феномен політичної культури в єдності із світовим культурним процесом і залежно від економічних, географічних, соціальних, психологічних, релігійних чинників аналізує С. Рябов [7-9]. Водночас, незважаючи на наявність значної кількості праць, проблема відслідковування зміни емансипаційних цінностей в окремих країнах в умовах демократизації суспільства залишається актуальною.

Метою нашого дослідження $є$ порівняльний аналіз емансипаційних цінностей українців із ціннісними орієнтаціями європейців у 2020 році та з'ясування, як ці орієнтації змінилися з 2011 року.

Аналізуючи феномен політичної культури, дослідники [5] виходять із того, що вона $є$ системою ставлень особистості та включає ставлення до самого себе, до інших і до чинного порядку, суспільного ладу, в умовах якого проходить життя людей. Звідси випливає ії розуміння як наслідку політичної соціалізації особистості. Таке уявлення не обмежує іiї знанням програм і позицій різних політичних сил, відданістю одній з них, оскільки в політиці цілком логічним є сусідство боротьби за владу та конструктивного мирного співіснування. А, отже, розгляд політичної культури та оцінка ії конкретного стану передбачає врахування не лише ставлення громадян до учасників політичного процесу, а ще й врахування і дотримання принципів соціальності, толерантності [5; 7].

Говорячи про демократичні перетворення в суспільстві, зауважимо, що їх необхідною передумовою та визначальним чинником $€$ зміна способу мислення людей та їхніх ціннісних орієнтацій. «Народ, що різко порвав зі своїм минулим, скоро підпадає під вплив сильної реакції, яка змушує його відступати. Аби переворот був міцним, треба змінити не уряд, а звичаї», - зазначав Монтеск'є. Проте дослідження, проведені в Україні, свідчать, що тут все ще домінують норми, установки, стереотипи й цінності, властиві тоталітарній культурі; залишається нерозвиненою психосоціальна ідентифікація груп населення; поширені невпевненість людей у власних можливостях, несамостійність, відчуття несвободи [5; 7; 9].

У суспільному дискурсі постійно присутня тема нагальних змін. Нинішній політичний режим наголошує на європейській інтеграції, реформах і наближенні до європейських цінностей. Проте варто враховувати, що модернізація не може зводитись до технологічних інновацій або економічного зростання, які, безумовно, $є$ важливими вимірами сучасного суспільства. Економічне зростання та інституційні зміни нерозривно пов'язані із соціокультурними перетвореннями та поширенням емансипаційних цінностей, критичного мислення, раціональної парадигми світосприйняття, довіри, толерантності, громадянської активності тощо. Вони є базовими принципами європейської культури, які можуть стати ключовими орієнтирами в модернізаційних стратегіях України [10]. Складний рух України до європейського співтовариства потребує значних модернізаційних змін, спрямованих на утворення структур підтримки демократичної культури. Дієвість таких змін великою мірою залежить від актуалізації відповідних державній культурі ціннісних орієнтирів.

Ціннісні зміни в окремих країнах $є$ предметом багаторічних досліджень у рамках світового проєкту World Values Survey. Поширення емансипаційних цінностей розглядається в контексті модернізаційних 
перетворень, таких як розширення сфери людського розвитку, глобалізаційні тенденції, соціально-економічне зростання, становлення демократичної культури [6].

Згідно із «Світовим Дослідженням Цінностей», яке було проведене у 2020 році, оцінка різних політичних систем в Україні змінилася з 2011 до 2020. Попри те, що громадяни оцінюють демократичну політичну систему як «дуже добру/добру» для управління Україною, однак з 2011 до 2020 року її підтримка суттєво знизилася: 3 85,3\% в 2011 році до $81,9 \%$ в 2020 році. Досить підтримуваною залишається політична система з сильним лідером, якого не обмежують ні уряд, ні вибори - у 2020 році таку систему оцінює як «дуже добру/добру» 67,9\% опитаних. Однак це менше, ніж в 2011 році (71,3\%). Знизилася підтримка політичної системи, де незалежні експерти приймають рішення, - 3 64,6\% до 46,2\%, і зросло позитивне ставлення до управління країною військовими (3 12,7\% до 21,1\%). $26,1 \%$ опитаних підтримують управління, при якому влада в руках духовенства і грунтується на релігійних законах [11, с. 195-196].

Хоча українці дають найбільше позитивних оцінок демократичній політичній системі як найкращій для України (66,9\% з урахуванням відповідей «важко сказати»), однак цей показник найнижчий серед всіх країн $€ С$, що включені до порівняння. Найближчими до України є Словаччина та Польща $(80,2 \%$ та $82,3 \%$ відповідно), однак, як бачимо, розрив є значним. Водночас українці чи не найбільше в Свропі прагнуть сильного лідера - 58,3\% опитаних. Їх випереджають лише румуни - 72,6\%. Натомість у Греції тільки 9\%, у Австрії - 14,2\%, у Фінляндії - 14,6\% підтримують таку політичну систему. Українців мало приваблює перспектива управління держави незалежними експертами - підтримує таку політичну систему лише 33,6\% опитаних. Цей показник є близьким до показника в Литві (34\%), однак він суттєво нижчий, ніж у більшості країн ЄС. Так, від 50\% до понад 70\% підтримали б таку політичну систему у Франції, Австрії, Фінляндії, Чехії, Іспанії, Естонії, Польщі, Словаччині тощо. Значно більшою мірою, ніж більшість європейців, українці схвалюють управління країни військовими (17,5\%). Цей показник є близьким до показника в Польщі (19,3\%), однак у більшості країн $Є С$, що були включені до порівняння, менше $10 \%$ опитаних ставляться позитивно до цього типу політичної системи. Найнижча підтримуваність у Німеччині $(1,4 \%)$ та Естонії $(3,7 \%)$. Дані про ставлення до управління країни релігійними лідерами станом на 2020 рік у вільному доступі були лише по окремих країнах. Проведений аналіз свідчить, що за цим показником Україну $(18,7 \%)$ випереджає лише Румунія $(25,3 \%)$, тоді як на Кіпрі (16,6\%), в Греції (10,0\%) і в Німеччині (2,6\%) рівень підтримки суттєво нижчий [11, с. 195-196].

Близько половини опитаних українців - 46,6\% не визначилися 3 оцінкою власного положення на політичній шкалі «лівий-правий», а розрахунок середнього значення відповідей тих, хто визначився, дозволив вирахувати середню оцінку 5,78 за 10-бальною шкалою (де 1 - лівий, 10 - правий). При цьому помітний зсув у «правий» бік із 2011 року (зі значення 5,49). Схожі показники маємо в Румунії $(5,77)$. Найвищі середні значення за середніми оцінками в Польщі $(6,24)$, а найнижчі - в Іспанії $(4,83)$ [11, c. 197].

Ще однією важливою характеристикою демократії є рівні права жінок і чоловіків. 84\% опитаних українців вибирають значення 7-10 за 10-бальною шкалою, де 10 - «важлива характеристика демократії». 32011 року зросла кількість респондентів, які відзначають важливість цієї характеристики (було $81,1 \%)$. Щоправда, порівняння з країнами ЄС дало змогу дійти висновку про їі недооцінку в Україні: важливою їі вважають 80,3\% українців (відповіді 7-10 за 10-бальною шкалою, з урахуванням відповідей «важко сказати»), тоді як у більшості країн $Є С$, включених до порівняння, важливим для демократії це вважають понад 80\% респондентів. Наприклад, у Греції - 95,3\%, в Данії - 94,6\%, Швеції - 94, 5\% тощо [11, с. 202].

Наступним за важливістю для українців йде вибір політичних лідерів на вільних виборах (76,2\%). Однак цей показник $є$ одним із найнижчих серед країн $\mathrm{CC}$, включених до порівняння. Нижчим він є в Румунії (74,3\%), Чехії (70,7\%), Франції (68,6\%) та Словаччині $(67,3 \%)$, тоді як для Греції, Данії, Швеції, Фінляндії та Німеччини він коливається на рівні 95\% [11, с. 202].

Наступною характеристикою демократії є важливість захисту громадянських прав. В Україні 72,6\% опитаних переконані, що громадянські права захищають людей від утисків із боку держави. 3 цим показником Україна знаходиться в середині списку з країн СС, включених до порівняння. Цю характеристику називають максимально важливою для демократії у Швеції (85\%), а мінімальний показник у Словаччини (57,7\%). Показники обох характеристик несуттєво змінились з 2011 року.

Також значна частка українців вважає, що демократія передбачає державну допомогу безробітним (79,1\%), стягування податків із багатих для підтримки бідних $(68,8 \%)$ та забезпечення рівності доходів $(66,5 \%)$, хоча спостерігаємо незначне зниження частки тих, хто поділяє таку думку (у 2011 році ці показники становили $82,4 \%, 71,4 \%, 68,1 \%$ відповідно). 
Державну допомогу безробітним важливою характеристикою демократії в Україні вважають 75,5\%. За цим показником Україну випередили лише деякі країни СС - Греція $(82,6 \%)$, Німеччина $(79,2 \%)$, Кіпр (78,2\%), Іспанія (78,2\%), Австрія (76\%), але в більшості країн СС про неї як важливу зазначає від половини до двох третин опитаних (в Чехії 44,3\%) [11, c. 201].

Так само вищою в Україні, ніж у більшості країн $Є С, \epsilon$ важливість такої характеристики як стягування податків із багатих для підтримки бідних. $63,7 \%$ українців переконані в тому, що уряд має стягувати податки з багатих для підтримки бідних. Для порівняння, аналогічної точки зору дотримуються в Нідерландах 57,3\% опитаних, в Данії - 54,5\%, в Естонії - 43,1\%, в Болгарії - 40,4\%, в Чехії - 25,0\%. Щоправда, цей показник є вищим, ніж в Україні, у Швеції (64,4\%), Фінляндії (64,5\%), Австрії (68,8\%) та Німеччині $(71,2 \%)$ [11, с. 201].

Частіше, ніж майже у всіх країнах $Є С$, включених до порівняння, в Україні вважають важливим для демократії забезпечення державою рівності доходів громадян (61,9\%). За цим показником Україну випередила тільки Італія (67,3\%). У більшості ж країн СС частка тих, хто так вважає, становить менше половини опитаних. А, наприклад, у Болгарії $(21,7 \%)$, Чехії $(19,0 \%)$, Швеція $(15,7 \%)$ цей показник є зовсім низьким [11, с. 205].

Близько половини українців вважає, що за демократії люди підкоряються своїм правителям, керівникам (48\%), і популярність такої думки значно зросла з 2011 року (32,7\%). Також більш популярними стали думки, що важливою характеристикою демократії є те, що армія бере владу, якщо уряд некомпетентний (з 25,9\% до 32,7\%), та що релігійні авторитети одноосібно тлумачать закони (з 17,7\% до 27,1\%) $[11$, c. 203].

В Україні оцінка важливості підкорення правителям та керівникам як важлива характеристика демократії є однією з найвищих в $Є С$ - так вважає $42,7 \%$. Лише в Іспанії та на Кіпрі ці цифри є вищими (відповідно, 46,9\% і 45,3\%). У більшості європейських країн, включених до порівняння, менше третини респондентів називають це важливим для демократії. Так, наприклад, у Данії - 32,3\%, Литві - 26,3\%, Естонії - 22,3\%, Нідерландах - 20,4\%, а Німеччині лише 8,4\% [11, с. 203].

Владу в руках армії за умови некомпетентності уряду важливою характеристикою демократії вважає меншість респондентів у всіх країнах СС. Проте Україна за цим показником у трійці лідерів: 27\% українців переконані у важливості, тоді як, наприклад, у Данії - 10,3\%, на Кіпрі - 7,6\%, в Німеччині $7,5 \%[11$, c. 206$]$.

Так само меншість у всіх країнах $Є С$ називає важливою характеристикою демократії одноосібне тлумачення законів релігійними авторитетами. Проте Україна $(22,7 \%)$ за середньою оцінкою знаходиться вище, ніж більшість країн $C C$ (відразу після Румунії (24,4\%)). У більшості країн $Є$ в важливим це назвали менше $15 \%$ (наприклад, у Німеччині лише $2,1 \%$, в Данії - 4,2\%, в Словенії - 6\%) [11, с. 206].

Частка осіб, які переконані у важливості жити в демократичній країні, з 2011 до 2020 року зросла $37,83 \%$ до 8,20\%. Однак за середньою оцінкою Україна знаходиться в низу рейтингу країн ЄС, включених до порівняння, поряд із Румунією $(8,25 \%)$ та Хорватією $(8,34 \%)$.

Також в Україні з 2011 до 2020 року зріс рівень позитивних оцінок необхідності поваги до прав людини: якщо у 2011 році 34,8\% наших співвітчизників були впевнені, що права людини в нашій державі поважають, то за 9 років таких осіб стало 45,6\%. Однак $54,4 \%$ опитаних все ще переконані, що права людини в Україні не поважаються. Проведений порівняльний аналіз із країнами СС дав змогу дійти висновку про те, що оцінки українців близькі до оцінок греків - у Греції $47,8 \%$ респондентів переконані, що права людини в їхній країні поважаються, а 49,8\% переконані у зворотному. У Німеччині найвищий відсоток тих, хто впевнений, що в країні поважають права людини $(91,4 \%)$, а найнижчий - у Румунії (29,9\%) [11, с. 214].

У сучасному світі спостерігаються відчутні ціннісні зміни, що демонструють перехід від матеріалістичних цінностей до цінностей постматеріалістичних. Про постматеріалізм вперше почав говорити американський дослідник Р. Інглхарт, наголошуючи на тому, що внаслідок задоволення матеріальних потреб в XX-XXI століттях і виникає цей перехід.

Світове дослідження цінностей 2020 в Україні показало несуттєве зменшення в Україні за 9 років сегмента матеріалістів (з 46,2\% в 2011 році до $45,9 \%$ у 2020 році) та сегмента змішаних (з 50,1\% в 2011 році до 49,5\% в 2020 році). Так само мало змінилася частка постматеріалістів (з 3,7\% в 2011 році до $4,6 \%$ в 2020 році), і вона є найменшою за розміром [11, с. 124].

Сегмент матеріалістів в Україні є найбільшим серед країн СС після Болгарії $(48,1 \%)$. Найменше матеріалістів маємо в Німеччині (7,5\%) та Швеції $(2,7 \%)$. Змішаний тип $є$ ознакою зміщення акцентів із матеріальних цінностей на постматеріальні і за розміром частки змішаного типу Україна знаходиться поруч із Болгарією (50,5\%) та Іспанією (50,9\%). Постматеріалістів в Україні чи не найменше в Свропі, 
окрім хіба що Болгарії $(1,4 \%)$. У більшості країн ЄС їх нараховується від $10 \%$ до 25\%. Найбільше в Німеччині $(36,9 \%)[11$, с. 125$]$.

Отже, збереження та зміцнення демократії безпосередньо пов'язане не лише 3 наявністю політичних еліт, які прагнуть розвивати демократію, а й зі зміною типу політичної культури. Р. Інглхарт та К. Вельцель пов'язують становлення демократії з постійною роботою з ціннісними орієнтаціями народу, які глибоко вкорінені в підсвідомості [3]. Проведений порівняльний аналіз емансипаційних цінностей українців із ціннісними орієнтаціями європейців уможливив висновок, що в Україні все ще домінують цінності, властиві тоталітарній культурі. Ціннісні орієнтації українців з 2011 року змінилися мало та часто не на краще: значно популярнішими стали думки про необхідність підкорення правителям, взяття влади до рук армією, якщо уряд некомпетентний, одноосібного тлумачення законів релігійними авторитетами. Водночас суттєво зросло розуміння необхідності поваги до прав людини в умовах демократії.

\section{Література:}

1. Alexander A., Welzel C. Islam and Patriarchy: How Robust is Muslim Support for Patriarchal Values? World Values Survey. 2011. P. 249-276.

2. Bauman Z. Globalizacja. Warszawa Państwowy Instytut Wydawniczy, 2000. $160 \mathrm{~s}$.

3. Inglehart R., Welzel Ch. Modernization, cultural change, and democracy : the human development sequence. Cambridge University Press; Illustrated edition. 2005. 344 p.

4. Welzel C. How Selfish Are Self-Expression Values? A Civicness Test. Journal of Cross-Cultural Psychology. 2010. № 41(2). P. 2-23.

5. Жадан І., Кисельов С., Кисельова О., Рябов С. Політична культура та проблеми громадянської освіти в Україні. Аналітичний звіт. Київ : Тандем, 2004. 80 с.

6. Кожем'якіна О.М. Емансипаційні цінності в суспільних трансформаціях: архетиповий підхід. Публічне урядування. 2016. № 2 (3). С. 104-112.

7. Короткий політологічний словник / За ред. С. Рябов, 3. Тимошенко. Київ : РОВО «Укрвузполіграф», 1991. 96 с.

8. Рябов С.Г. Громадянське суспільство та політична культура. Україна в сучасному світі : конференція випускників програм наукового стажування у США, м. Ялта, 12-15 вересня 2002 р. / ред. кол. О.В. Гарань [та ін.]; Kennan Institute; Woodrow Wilson International Center for Scholars. Київ : Стилос, 2003. С. 273-283.

9. Рябов С.Г. Особливості громадянської освіти у формуванні політичної культури перехідного суспільства. Наукові записки НаУКМА. 2004. Т. 31: Політичні науки. С. 54-64.

10. Савельєв Ю.Б. Емансипаційні цінності і толерантність у контексті модернізації українського суспільства. Український соиіум. 2015. № 1 (52). С. 68-81.

11. Світове дослідження цінностей 2020 в Україні. URL: http://ucep.org.ua/wp-content/uploads/2020/11/WVS_UA_2020_ report_WEB.pdf. 